\title{
ISOLATION, CHARACTERIZATION AND INOCULUM FORMULATION OF NODULE FORMING BACTERIA OF KUDZU (Pueraria phaseoloides (Roxb.)Benth.) FOR COASTAL SANDY LAND CONSERVATION
}

\author{
Nike Triwahyuningsih ${ }^{1^{*}}$ and Tati Budi Kusmiyarti ${ }^{2}$ \\ ${ }^{1}$ Department of Forestry, Faculty of Forestry, Institut Pertanian INTAN Yogyakarta, \\ Jl. Magelang Km 5,6 Yogyakarta \\ ${ }^{2}$ Department of Agroecotechnology, Agriculture Faculty, Udayana University, Bali \\ *Coresponding Author: niketriwahyu@gmail.com
}

\begin{abstract}
Kudzu plantation (Pueraria phaseoloides) as legume cover crop is one of alternatives in coastal sandy land conservation. The crops are known to associate with a root nodule-forming bacteria (Rhizobium sp.) which give some benefits to nutrient cycling i.e. : atmospheric $\mathrm{N}_{2}$ fixing and play role as soil conditioner; soil Nitrogen enrichment; nutrient cycling; and increasing other nutrients availability. A research to study the isolation dan bacterial inoculum multiplication from wild kudzu root nodules, compatible isolates screening and selected isolates multiplication, and examining the form, amounts and most proper inoculum application method was conducted in Greenhouse and Laboratory of Microbiology in Yogyakarta province.

The research were held in four phases : (1) isolation, purification and characterization of isolates; (2) reinoculation dan compatibility testing of isolates to kudzu seeds; (3) inoculum multiplication; and (4) examination of the form, amounts and most proper inoculum application method. Physical and biochemical properties of the isolates were observed during the isolation phase. Infection and nodulation activity were observed during the reinoculation phase. Indirectly counting of the microbial numbers to obtain the cell numbers was conducted during the inoculum multiplication. While infection and nodulation activity and plant growth were observed during the inoculum testing phase.

Isolates purification on Yeast Mannitol Agar + congo-red media gave 5 different isolates named RP-Etp1, RP-Etp2, RP-Etp3, RP-Etp4, RP-Etp5. The RP-Etp4 isolate had the highest compatibility to the kudzu seeds (number of effective nodules $>100$ per plant), followed by RPEtp5 (medium compatibility, number of effective nodules 50-100 per plant), RP-Etp1 and RPEtp3 (low compatibility, number of effective nodules $<10$ ). Isolate RP-Etp2 was incompatible to the kudzu.

Optimum cell numbers was reached in 48 hours incubation time. Application of broth/liquid inoculum of Rhizobium sp. has advantages over solid inoculum (in peat) as it gives the highest number of nodules, and the optimum dosage was $2-4 \mathrm{ml}$ per plant. The highest infectionnodulation activity and plant growth were reached in $4 \mathrm{ml}$ inoculum per plant (direct application) or $2 \mathrm{ml}$ inoculum per plant (weekly applied in two weeks).
\end{abstract}

Keywords: isolation, characterization, inoculum formulation, Rhizobium sp., Kudzu

\section{INTRODUCTION}

Coastal sandy land of the southern region of Yogyakarta Special Regency is one of the most critical lands that meets several restriction for crop cultivation. Nevertheless, this area provides huge potential to managed 
and used to improve the local/domestic revenue. The main obstacles to manage the critical area are : low soil fertility; low in soil mineral content; unfavorable microclimates; high wind and water erosion; few in propagules of soil fertilizing microbes; and low quality and quantity of managing human resources.

\section{Cultivation of kudzu (Pueraria} phaseoloides), familia Fabaceae,as a legume cover crop (LCC) is one of the alternatives to conserve the critical coastal land. The crops are known to associate to a root noduleforming bacteria (Rhizobium sp.) which give some benefits to nutrient cycling i.e. : atmospheric $\mathrm{N}_{2}$ fixing and play role as soil conditioner; soil Nitrogen enrichment; nutrient cycling; and increasing other nutrients availability. Nitrogen accumulation on topsoil is reach 8 to 14 times higher if compared to the biomass nitrogen content. The more the biomass production brings the higher Nitrogen mineralization in soil, and significantly increase the nutrient cycling, reduce the nutrien leaching, and increase the other mineral content (i.e. K content) in topsoil (Lehmann et al., 2000).

Kudzu is a beneficial herbs, not just an invaders, which give benefits to human (leaves for tea, bean for coffee and tempeh, flower for vegetable food ingredients),livestock forage, industrial fiber and textile. According to Ashton (2017), kudzu contains a variety of phytochemicals, which are potent antioxidant compounds found naturally in plants, that help to prevent and treat human disease. Kudzu contains the phytochemicals quercetin, which has antihistamine and anti-inflammatory properties, and genistein which works as a free radical scavenger. The most important phytochemicals are, however, the isoflavone compounds -- daidzein, daidzin, tectorigenin and puerarin.

The kudzu LCC plantation are also meet the ecosystem benefits such as protecting the topsoil from erosion, soil bulking agents, increasing soil organic matters, increasing the fertilizing microbe propagules, improve soil moisture, increasing mineral availability, and improving soil aeration. The wide and deep root system of kudzu take the important roles for prevent soil erosion, reduce water run-off to prevent landslides, and to increase land productivity. The kudzu plants are also known to be a well adapted plants to critical dry climate and have the ability to grow on extremely acidic or basic soil.

The success of Kudzu cultivation in extremely critical coastal sandy land can be increased by inoculating root nodule forming bacteria. Application of indogenous inoculum from wild Kudzu significantly improved the infection activity and increased plant growth (Nike-Triwahyuningsih et al., 2005). The research obviously gave a clear evidence that 
the Kudzu root nodules indigenous can be used as a source of natural inoculum.

Availability of information on the inoculum form, amount and application method are important part of this research, in order to provide sources of inoculum. Therefore the research was aimed to : (1) isolate the rhizobial bacteria from the root nodules of wild kudzu to obtain the effective isolates; (2) characterize and determine the pure isolates and to reproduce the inoculum; (3) reinoculate the pure isolates to obtain the selected effective isolates to stimulate the root nodules formation, and (4) reproduce the selected inoculum and to test the form, amount and application method to obtain the effective ones.The targetes of the research were : (1) isolation and characterization of the indigenous isolates; (2) inoculum reproduction; (3) formulation and reinoculation on the cultivated Kudzu.

\section{MATERIALS AND METHODS}

Several materials were used in this research. Wild kudzu plants with intact root nodules used as source of indigenous inoculum. Yeast Mannitol Agar (YMA) was used to reproduce inoculum, and Yeast Mannitol Broth (YMB) to cultivation, isolation and enumeration of Rhizobium spp. Kudzu seeds used to test the effectivity of the selected pure inoculum in coastal sandy soil media. The overal procedures and phases of the research were as follow:

Phase I : Harvesting of wild Kudzu in coastal sandy land to provide the root nodules and indigenous isolates. Isolation and purification of isolates on YMA to obtain the pure isolates that will be compatibility tested in phase III.

Phase II : 1. Characterization and determination of all the pure isolates grew on the YMA. The physical properties (colony form, edges, elevation, and inner structure) and physiological properties of bacterial isolates (gram, acid neutralization) were observed.

2. Reproduction of inoculum I. Every purified isolate than multiplied in YMBto obtain the optimum amount of inoculum (the amount of cells reachup to $\left.10^{7}-10^{8} \mathrm{CFU} / \mathrm{ml}\right)$. 
Phase III : Reinoculation and compatibilty testing of isolates to Kudzu planted in coastal sandy soil media, to collect the selected pure isolates. The experiment was arranged in a single factorial completely randomized design to test the compatibilty of each isolate.

Phase IV : Reproduction of inoculum II in order to multiply the selected compatible inoculum. The multiplication process was conducted to obtain the sufficient amount of inoculum.

Phase V : Examination on concentration, form and application method of selected inoculum. The experiments were simultaneously conducted and arranged in factorial completely randomized design with three replications.

Experiment 1 : to examine the concentration and inoculum form,

Experiment 2 : to examine the concentration and application method.

All the influences of treatments were observed on :

Infection and nodulation activity

Kudzu plant growth

\section{RESULTS AND DISCUSSION}

A. Isolation and Purification of Root Nodule Rhizobium sp. From Wild Kudzu

In order to obtain the Rhizobium sp. isolate, the root nodules of wild Kudzu were collected from Bugel Panjatan coastal sandy land, district of Kulonprogo DIY. The nodules extract was inoculated in a surface plating isolates method on YMA media with congo-red. According to the form and color of isolates, it was obtained 7 different kinds of isolate namely K1, K2, K3, K4, K5, K6, K7. Each single isolates then purified by repeatedly reinoculation, and the pure culture then preserved in a tilted YMA media (Jutono,1980). The description of each 
Table 1. Description of Rhizobium sp. isolates obtained from root nodules of wild Kudzu

\begin{tabular}{lccccccc}
\hline Description & \multicolumn{1}{c}{ K1 } & K2 & K3 & K4 & K5 & K6 & K7 \\
\hline Color & Pink ++ & Pink +++ & Pink + & Clear & Clear & Red & Pink \\
Colony form & Circular & Circular & Circular & Circular & Circular & Circular & Circular \\
Diameter & $\pm 5 \mathrm{~mm}$ & $\pm 1 \mathrm{~mm}$ & $\pm 3 \mathrm{~mm}$ & $\pm 1 \mathrm{~mm}$ & $\pm 1 \mathrm{~mm}$ & $\pm 1 \mathrm{~mm}$ & $\pm 2 \mathrm{~mm}$ \\
Elevation & Pulvinate & Convex & Pulvinate & Convex & Convex & Convex & Effuse \\
Edge form & Lobate & Erose & Crenate & Undulate & Entire & Undulate & Lobate \\
$\begin{array}{l}\text { Inner } \\
\text { structure }\end{array}$ & $\begin{array}{l}\text { Finely } \\
\text { granular }\end{array}$ & $\begin{array}{l}\text { Coarsely } \\
\text { granular }\end{array}$ & $\begin{array}{l}\text { Finely } \\
\text { granular }\end{array}$ & $\begin{array}{l}\text { Finely } \\
\text { granular }\end{array}$ & $\begin{array}{l}\text { Finely } \\
\text { granular }\end{array}$ & $\begin{array}{l}\text { Finely } \\
\text { granular }\end{array}$ & $\begin{array}{l}\text { Finely } \\
\text { granular }\end{array}$ \\
Mucus & + & + & ++++ & + & +++ & + & - \\
\hline
\end{tabular}

Note : K is a symbol of Kudzu Rhizobium sp., 1-7 are number of isolate.

All the 7 isolates have a common similarity, that are circular colony form. The differences are on the color of colony (pink and clear), diameter (1-5 mm), elevation (pulvinate, convex and effuse), edge form (lobate, erose, crenate, undulate dan entire) and the inner structure (finely granular and coarsely granular). Purification of all the isolate results showed that isolate $\mathrm{K} 1$ similar to $\mathrm{K} 4, \mathrm{~K} 2$ similar to K6. Therefore 5 different isolates were obtained, and were named by isolate RP-Etp1 (from $\mathrm{K} 1+\mathrm{K} 4)$, RP-Etp2 (from K2+K6), RP-Etp3 (from K3), RP-Etp4 (from K5), and RP-Etp5 (from K7) described as follows.

Table 2. Description of the purified isolates

\begin{tabular}{llllll}
\hline \multicolumn{1}{c}{ Description } & \multicolumn{1}{c}{ RP-Etp1 } & RP-Etp2 & RP-Etp3 & RP-Etp4 & \multicolumn{1}{c}{ RP-Etp5 } \\
\hline Color & Pink ++ & Pink +++ & Pink + & Clear & Pink \\
Colony form & Circular & Circular & Circular & Circular & Circular \\
Diameter & $\pm 5 \mathrm{~mm}$ & $\pm 1 \mathrm{~mm}$ & $\pm 3 \mathrm{~mm}$ & $\pm 1 \mathrm{~mm}$ & $\pm 2 \mathrm{~mm}$ \\
Elevation & Pulvinate & Convex & Pulvinate & Convex & Effuse \\
Edge form & Lobate & Erose & Crenate & Entire & Lobate \\
Inner structure & Finely & Coarsely & Finely & Finely & Finely \\
& granular & granular & granular & granular & granular \\
Mucus & + & + & ++++ & +++ & - \\
\hline
\end{tabular}

Note : RP-Etp = Rhizobium sp., isolate of Pueraria in Entisol coastal sandy soil

The abbreviation of RP refers to the species name (Rhizobium sp.), and Etp refers to the origin of the soil classification (Entisol soil of coastal land = Entisol pasir pantai, Ind.). 
All the 5 isolates have common preserved in tilted YMA media with congosimilarities in colony form (Circular) and the red.

differences are in the color of colony (pink and clear), diameter (1-5 $\mathrm{mm})$, elevation (pulvinate, convex and effuse), edge form (lobate, erose, crenate, undulate and entire) and the inner structure (finely granular and coarsely granular). And the name isolates are RP-Etp1, RP-Etp2, RP-Etp3, RP-Etp4, and

\section{B. Characterization of Purified Isolates}

The aims of the characterization are to obtain the description of all the purified isolates and to examine the compatibility to the Kudzu seeds. The characterization of purified isolates are shown in Table 3.

RP-Etp5. These isolates then collected as a source of inoculum. The purified isolates then

Table 3. Characterization of purified isolates

\begin{tabular}{|c|c|c|c|c|c|c|}
\hline Description & $\begin{array}{l}\text { Rhizobium } \\
\text { (Elkan,1987) }\end{array}$ & RP-Etp 1 & RP-Etp2 & RP-Etp3 & RP-Etp4 & RP-Etp5 \\
\hline \multicolumn{7}{|c|}{ Colony Characterization } \\
\hline Color & Clear white & Pink ++ & Pink +++ & Pink + & Pink ++ & Red ++++ \\
\hline Colony form & Circular & Circular & Circular & Circular & Circular & Circular \\
\hline Diameter & $1-5 \mathrm{~mm}$ & $\pm 1 \mathrm{~mm}$ & $\pm 1 \mathrm{~mm}$ & $\pm 1 \mathrm{~mm}$ & $\pm 2 \mathrm{~mm}$ & $\pm 1 \mathrm{~mm}$ \\
\hline Elevation & $\begin{array}{l}\text { Plate- } \\
\text { Convex }\end{array}$ & Convex & Convex & Convex & Convex & Convex \\
\hline Edge form & - & Lobate & Undulate & Lobate & Undulate & Undulate \\
\hline Inner structure & $\begin{array}{l}\text { Opaque- } \\
\text { Transclusent }\end{array}$ & $\begin{array}{l}\text { Finely } \\
\text { granular }\end{array}$ & $\begin{array}{l}\text { Corsely } \\
\text { granular }\end{array}$ & $\begin{array}{l}\text { Finely } \\
\text { granular }\end{array}$ & NA & NA \\
\hline Mucus & + & + & + & + & - & ++++ \\
\hline Growing type & $\begin{array}{l}\text { Fast / slow } \\
\text { growing }\end{array}$ & $\begin{array}{l}\text { slow } \\
\text { growing }\end{array}$ & $\begin{array}{l}\text { slow } \\
\text { growing }\end{array}$ & $\begin{array}{l}\text { slow } \\
\text { growing }\end{array}$ & $\begin{array}{l}\text { slow } \\
\text { growing }\end{array}$ & $\begin{array}{l}\text { slow } \\
\text { growing }\end{array}$ \\
\hline Motility & motile & motile & non motile & non motile & motile & motile \\
\hline \multicolumn{7}{|c|}{ Cell Characterization } \\
\hline Cell form & $\begin{array}{l}\text { Bacilus or } \\
\text { pleiomorfik }\end{array}$ & spheroid & apiculate & elongate & spheroid & spheroid \\
\hline Gram properties & negative & negative & negative & negative & negative & negative \\
\hline Aerobisity & anaerob & microaerob & microaerob & microaerob & microaerob & microaerob \\
\hline $\begin{array}{l}\mathrm{NO}_{2} \text { reduction } \\
\text { capability }\end{array}$ & + & + & + & + & + & + \\
\hline $\begin{array}{l}\mathrm{CO}_{2} \text { forming } \\
\text { capability }\end{array}$ & + & - & + & + & + & + \\
\hline $\begin{array}{l}\text { Carbohydrate } \\
\text { reduction } \\
\text { capability }\end{array}$ & + & + & + & + & + & + \\
\hline Life type & $\begin{array}{l}\text { Khemo- } \\
\text { heterotrofik }\end{array}$ & $\begin{array}{l}\text { Khemo- } \\
\text { heterotrofik }\end{array}$ & $\begin{array}{l}\text { Khemo- } \\
\text { heterotrofik }\end{array}$ & $\begin{array}{l}\text { Khemo- } \\
\text { heterotrofik }\end{array}$ & $\begin{array}{l}\text { Khemo- } \\
\text { heterotrofik }\end{array}$ & $\begin{array}{l}\text { Khemo- } \\
\text { heterotrofik }\end{array}$ \\
\hline
\end{tabular}


According to Elkan (1987), Rhizobium sp. has a milky white or clear color of colony, but in this research the isolates did not perform the real color since the pink-red color originated from the congo-red of YMA media. Application of congo-red is as indicator of colony viability, where it means that the colony is viable. Rhizobium sp. usually has colony diameter $1-5 \mathrm{~mm}$, and all the purified colony have diameter 1-2 $\mathrm{mm}$, that indicated the slow growing strains. The colony form (circular), elevation (plate-convex) and mucus (abundant) are as stated by Elkan (1987). But, the inner structure of the purified Rhizobium colony (finely granular and coarsely granular) is differ from the one stated by Elkan (opaqe and transclusent). This character indicated that the Rhizobium of Kudzu probably has different strain.

The cell characterization results showed that all the purified isolates has a gram negative properties. According to Tortora (2001), Rhizobium sp. is gram negative, and it indicates that the strain has the hydrophobic lipopolysaccharide cell wall, so it capable to resist to the unfavorable environment. This is why the strain have capability to survive in the environment with extremely dryness, low nutrient level and low acidity.
According to the aerobocity properties, all the Rhizobium isolated are microaerobic which obviously different from anaerobic character as stated by Elkan (1987), and this probably came from different strain of Rhizobium sp. Isolates of Kudzu Rhizobium sp. need litlle oxygen as an energy source and seemly can survive in coastal sandy soil with extremely dryness and lack of nutrients.

All the Rhizobium isolates showed the capability to reduce nitrite and nitrate based on the nitrification testing. This indicates that all the isolates capable in forming root nodules and sinthesizing proteins. And according to the fermentation test, all the isolates capable to reduce amylum, glucose and sucrose, which mean that all the isolates have the capability to reduce carbohydrate and producing energy needed for cell growth and development.

\section{Compatibility Examination of Selected Isolates}

In order to observe the isolate capability to infect and to form root nodule on kudzu plants, the selected isolates were reinoculated to the 3 months old kudzu seedlings and the result showed in the following Table 4 . 
ISOLATION, CHARACTERIZATION AND INOCULUM FORMULATION OF NODULE FORMING BACTERIA OF KUDZU (Pueraria phaseoloides (Roxb.)Benth.) FOR COASTAL SANDY LAND CONSERVATION Nike Triwahyuningsih and Tati Budi Kusmiyarti

Table 4. Influence of selested isolates reinoculation on infection and nodulation activity of kudzu plants on week 10

\begin{tabular}{|c|c|c|c|c|c|c|c|c|c|}
\hline \multirow{3}{*}{$\begin{array}{c}\begin{array}{c}\text { Infection and } \\
\text { Nodulation Activity }\end{array} \\
\text { Numbers of total nodules }\end{array}$} & \multicolumn{9}{|c|}{ Isolates } \\
\hline & \multirow{2}{*}{$\frac{\text { RP-Etp1 }}{1,66}$} & \multicolumn{2}{|c|}{ RP-Etp2 } & \multicolumn{2}{|c|}{ RP-Etp3 } & \multicolumn{2}{|c|}{ RP-Etp4 } & \multicolumn{2}{|c|}{ RP-Etp5 } \\
\hline & & 0,00 & $\mathrm{c}$ & 1,00 & $\mathrm{~b}$ & 126,50 & $\mathrm{a}$ & 94,83 & $\mathrm{a}$ \\
\hline $\begin{array}{l}\text { Numbers of effective } \\
\text { nodules }\end{array}$ & $b^{1,33}$ & 0,00 & $\mathrm{c}$ & 0,33 & $\mathrm{~b}$ & 113,67 & $\mathrm{a}$ & 87,33 & $\mathrm{a}$ \\
\hline $\begin{array}{l}\text { Effective nodules } \\
\text { percentage }(\%)\end{array}$ & $\begin{array}{l}80,00 \\
a\end{array}$ & 0,00 & $b$ & 33,00 & $\mathrm{~b}$ & 86,69 & & 90,46 & $\mathrm{a}$ \\
\hline $\begin{array}{l}\text { Total nodules weight } \\
\text { (grams) }\end{array}$ & $b^{0,006}$ & 0,00 & $\mathrm{c}$ & 0,003 & $\mathrm{~b}$ & 0,67 & & 0,59 & $\mathrm{a}$ \\
\hline Compatibility & + & - & & + & & +++ & & ++ & \\
\hline
\end{tabular}

Notes : Values followed by different letter in the same row indicate the significantly differences according to the F-table 5\%

Isolate RP-Etp2 clearly incompatible to Kudzu plants since it can not infected and formed root nodules. Otherwise, RP-Etp4 and RP-Etp5 showed the highest compatibility to the plants since it gave highest amount and size of nodules, and gave highest amount of effective nodules. Meanwhile the isolates of RP-Etp1 and RP-Etp3 showed the unsignificant compatibility. The infection and nodulation capability of Rhizobium isolates indicated the survival capability of bacterial strains in unfavorable environment. The highest compatibility of isolates bring the better plant growth, as shown in Table 6 .

Table 5. Influence of selected isolates reinoculation on plant height, leaves number, root fresh weight, biomass fresh weight, and biomass dry weight on week 10

\begin{tabular}{lccccc}
\hline \multirow{2}{*}{ Plant Growth } & \multicolumn{5}{c}{ Isolates } \\
\cline { 2 - 6 } & RP-Etp1 & RP-Etp2 & RP-Etp3 & RP-Etp4 & RP-Etp5 \\
\hline Plant height (cm) & $57,73 \mathrm{~b}$ & $52,53 \mathrm{~b}$ & $37,33 \mathrm{~b}$ & $202,61 \mathrm{a}$ & $140,03 \mathrm{a}$ \\
Leaves number & $11,11 \mathrm{~b}$ & $10,00 \mathrm{~b}$ & $10,33 \mathrm{~b}$ & $24,94 \mathrm{a}$ & $13,55 \mathrm{~b}$ \\
Root fresh weight (grams) & $2,47 \mathrm{a}$ & $2,30 \mathrm{a}$ & $2,07 \mathrm{a}$ & $2,41 \mathrm{a}$ & $1,39 \mathrm{~b}$ \\
Biomass fresh weight (grams) & $30,22 \mathrm{a}$ & $17,49 \mathrm{~b}$ & $36,51 \mathrm{a}$ & $43,50 \mathrm{a}$ & $26,13 \mathrm{ab}$ \\
Biomass dry weight (grams) & $5,93 \mathrm{~b}$ & $4,14 \mathrm{ab}$ & $6,27 \mathrm{a}$ & $11,84 \mathrm{a}$ & $5,27 \mathrm{~b}$ \\
Shoot:Root ratio & $12,23 \mathrm{ab}$ & $7,60 \mathrm{c}$ & $17,63 \mathrm{ab}$ & $18,05 \mathrm{a}$ & $18,79 \mathrm{a}$
\end{tabular}

Notes : Values followed by different letter in the same row indicate the significantly differences according to the F-table $5 \%$ 
The Kudzu plants infected by the incompatible RP-Etp2 showed lowest growth of shoot and roots. The incompatibility indicated that the RP-Etp2 strain has unability in biological nitrogen fixation to provide proteins. Otherwise, the RP-Etp4 strain showed highest performance of plant growth to be followed by RP-Etp5, RP-Etp3 and RPEtp1 respectively.

The effective root nodules are characterized by the red-pink color whenever it squeezed. The red color come from the leghemoglobin (legHb or symbiotic $\mathrm{Hb}$ ), a nitrogen carrier or oxygen carrier and hemoprotein found in nitrogen fixing leguminous root nodules. It is produced by legumes in response to the roots being colonized by nitrogen-fixing rhizobacteria (Rhizobium), as part of the symbiotic interaction between plant and bacterium.
Roots not colonized by Rhizobium do not synthesize leghemoglobin. Leghemoglobin has close chemical and structural similarities to hemoglobin, and, like hemoglobin, is red in colour. The holoprotein (protein + heme cofactor) is widely believed to be a product of both plant and the bacterium in which the apoprotein is produced by the plant and the heme (an iron atom bound in a porphyrin ring) is produced by the bacteroids (O'Brian et al., 1987). Some evidence, however, suggests that the heme moiety is also produced by the plant (Santana et al., 1998). The morphological photograph of the Kudzu root nodule are shown in Fig. 1 and Fig. 2. Nodules attached to the root by a long stalk (A) or short stalk (B), and the legHb producing bacteroids live in cortical cells of root nodules.

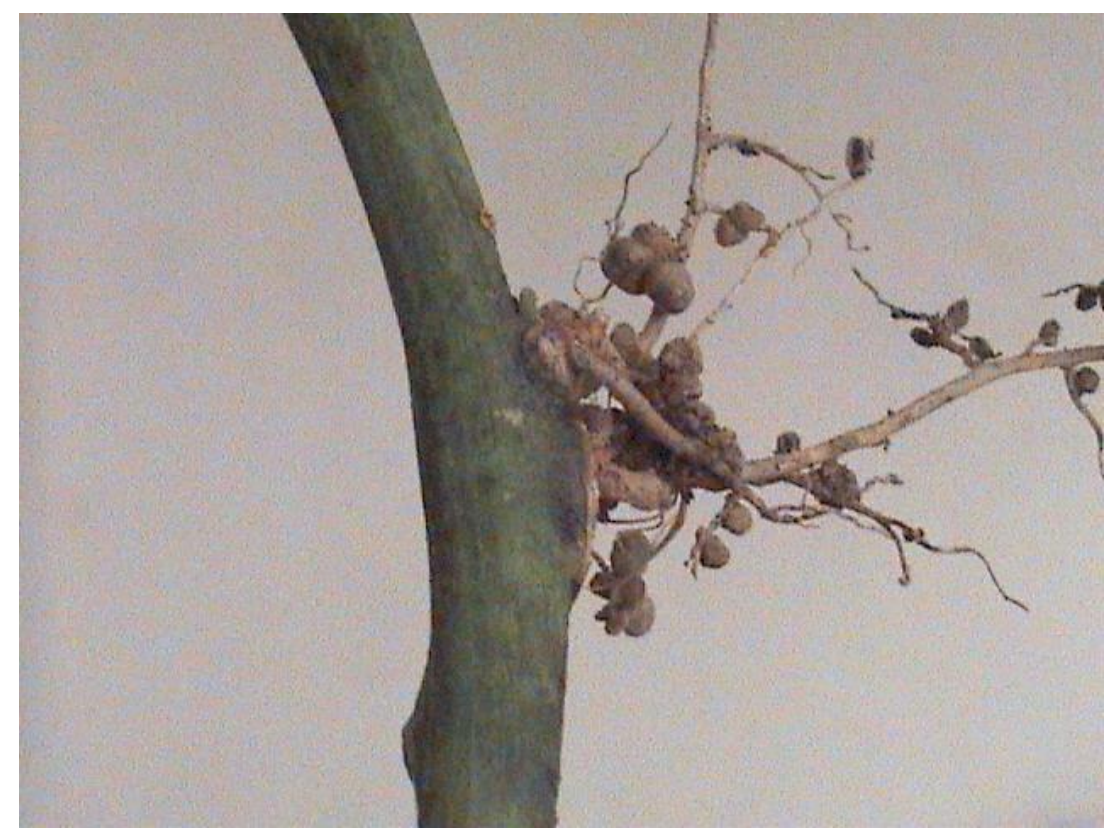

Fig. 1. Morphological photograph of Kudzu root nodules 


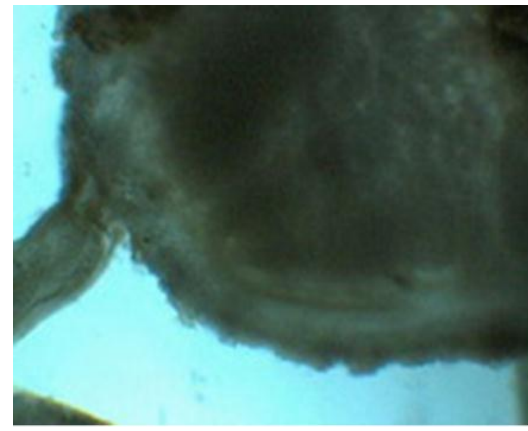

(A)

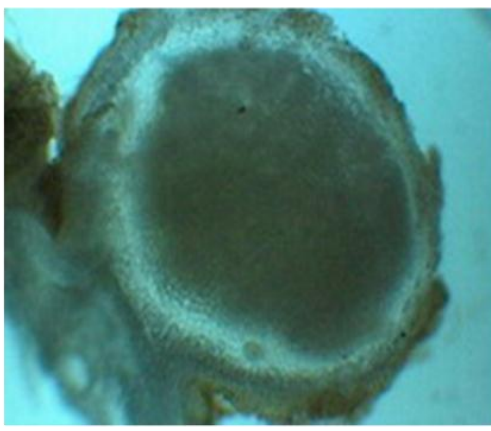

(B)

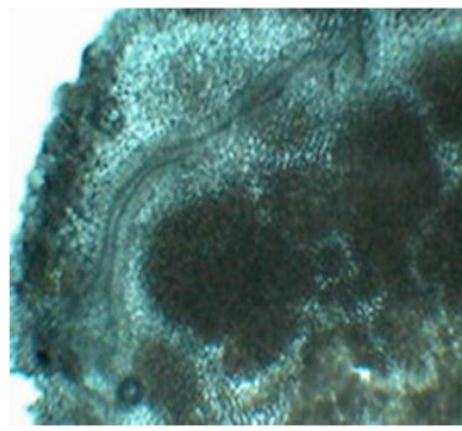

(C)

Fig. 2. Longitudinal cross section of Kudzu root nodules (A. nodule with long stalk; B. nodule with short stalk; $\mathrm{C}$. bakteroid in root nodule cortical cells)

\section{Inoculum Multiplication}

Multiplication of isolates was aimed to reproduce the stock inoculum used in reinoculation phase. To reach the appropriate cell amount, isolates were incubated in a shake culture for 72 hours and the cell numbers were calculated by plating method and observed after 24, 48 and 72 hours. According to Elkan (1987), the prefered amount of inoculum are $10^{8}-10^{9} \mathrm{CFU} / \mathrm{ml}$, and the calculation results are shown in the following Table 6 .

Table 6. The effect of incubation period on cell numbers ofRhizobium sp. (RP-Etp4)

\begin{tabular}{lrrrr}
\hline Incubation & \multicolumn{4}{c}{ Average cell numbers (CFU/ml) } \\
\cline { 2 - 5 } \multicolumn{1}{c}{ period } & Isolate I & Isolate II & Isolate III & Average \\
\cline { 2 - 5 } 24 hours & $1,32 \times 10^{7}$ & $2,10 \times 10^{7}$ & $2,72 \times 10^{7}$ & $2,05 \times 10^{7}$ \\
48 hours & $149,50 \times 10^{8}$ & $149,70 \times 10^{8}$ & $149,00 \times 10^{8}$ & $149,40 \times 10^{8}$ \\
72 hours & $80,00 \times 10^{8}$ & $1,56 \times 10^{8}$ & $4,97 \times 10^{8}$ & $27,19 \times 10^{8}$ \\
\hline
\end{tabular}

Incubation period obviously affected the cell numbers. During the 24 hours of hours. incubation, bacterial cells adapted to grow in lag phase, and after 48 hours the growing are even faster and then slowing after 72 hours. The bacterial cell amount after $48-72$ hours of incubation are appropriate for inoculum. According to the incubation results, inoculums prepared after incubated for 48

E. The Examination of Inoculum Concentration and Form of Isolate RPEtp4

The inoculum form and amount affected the effectiveness of infection and 
nodulation of Rhizobacteria. Generally, the bacterial inoculum applied in liquid/broth or solid form. The broth inoculum is Rhizobium inoculum grown on YMB medium and incubated for at least 48 hours. Whereas the solid inoculum is made by mixing the broth inoculum into a peat carrier (peat). The in Table 8 .

Table 7. Influence of inoculum form and concentration of Rhizobium sp. to the development of Kudzu nodule at week 10

\begin{tabular}{lccccc}
\hline Inoculation treatments & $\begin{array}{c}\text { Number of } \\
\text { total nodules }\end{array}$ & $\begin{array}{c}\text { Effective } \\
\text { nodul (\%) }\end{array}$ & $\begin{array}{r}\text { Number of } \\
\text { effective } \\
\text { nodules }\end{array}$ & $\begin{array}{c}\text { Total } \\
\text { nodules } \\
\text { weight (g) }\end{array}$ & $\begin{array}{c}\text { Symbiosis } \\
\text { effevtiveness }\end{array}$ \\
\hline Broth inoculum & $154,17 \mathrm{a}$ & $88,89 \mathrm{a}$ & $138,5 \mathrm{a}$ & $0,98 \mathrm{a}$ & $1,54 \mathrm{a}$ \\
Solid inoculum & $98,50 \mathrm{a}$ & $85,74 \mathrm{a}$ & $86,17 \mathrm{a}$ & $0,37 \mathrm{~b}$ & $20,31 \mathrm{a}$ \\
Conc. 2ml/plant & $126,50 \mathrm{p}$ & $86,69 \mathrm{p}$ & $113,67 \mathrm{p}$ & $0,67 \mathrm{p}$ & $31,43 \mathrm{p}$ \\
Conc. 4 ml/plant & $126,17 \mathrm{p}$ & $87,94 \mathrm{p}$ & $111,00 \mathrm{p}$ & $0,68 \mathrm{p}$ & $-9,57 \mathrm{p}$ \\
Factorial & $126,33 \mathrm{x}$ & $87,32 \mathrm{x}$ & $112,33 \mathrm{x}$ & $0,68 \mathrm{x}$ & $10,92 \mathrm{x}$ \\
Control & $149,33 \mathrm{x}$ & $87,05 \mathrm{x}$ & $130,00 \mathrm{x}$ & $37,67 \mathrm{x}$ & $0,00 \mathrm{y}$ \\
Interaction & $(-)$ & $(-)$ & $(-)$ & $(-)$ & $(-)$ \\
\hline
\end{tabular}

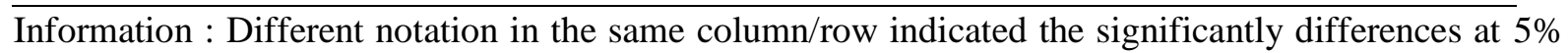
F-test

There is no interaction between form and concentration of inoculum that should be given. Broth inoculum has advantages over solid inoculum because it gives a significantly better crop length (Table 8). Meanwhile, the concentration or dose of inoculum, either 2 or $4 \mathrm{ml} /$ plant, gives relatively the same effect on infection and nodulation.

higher of total nodule weight (Table 7) and 
Table 8. Effect of treatments on the growth of Kudzu plants at week 10

\begin{tabular}{lccrcrrr}
\hline $\begin{array}{c}\text { Inoculation } \\
\text { treatments }\end{array}$ & $\begin{array}{c}\text { Root fresh Root dry } \\
\text { wt } \mathbf{( g )}\end{array}$ & $\begin{array}{c}\text { Plant } \\
\text { wt } \mathbf{( g )}\end{array}$ & $\begin{array}{c}\text { height } \\
(\mathbf{c m})\end{array}$ & $\begin{array}{c}\text { Leaves } \\
\text { number }\end{array}$ & $\begin{array}{c}\text { Number } \\
\text { of } \\
\text { segment }\end{array}$ & $\begin{array}{c}\text { Biomass } \\
\text { fresh wt } \\
(\mathbf{g})\end{array}$ & $\begin{array}{c}\text { Biomass } \\
\text { fresh wt } \\
(\mathbf{g})\end{array}$ \\
\hline Broth inoculum & $3,02 \mathrm{a}$ & $0,84 \mathrm{a}$ & $227,17 \mathrm{a}$ & $27,27 \mathrm{a}$ & $36,61 \mathrm{a}$ & $44,37 \mathrm{a}$ & $10,01 \mathrm{a}$ \\
Solid inoculum & $2,15 \mathrm{a}$ & $0,81 \mathrm{a}$ & $176,89 \mathrm{~b}$ & $24,50 \mathrm{a}$ & $31,44 \mathrm{a}$ & $32,42 \mathrm{a}$ & $10,53 \mathrm{a}$ \\
Conc. $2 \mathrm{ml} / \mathrm{plant}$ & $2,41 \mathrm{p}$ & $0,74 \mathrm{p}$ & $202,61 \mathrm{p}$ & $24,94 \mathrm{p}$ & $33,50 \mathrm{p}$ & $43,50 \mathrm{p}$ & $11,84 \mathrm{p}$ \\
Conc. $4 \mathrm{ml} / \mathrm{plant}$ & $2,75 \mathrm{p}$ & $0,91 \mathrm{p}$ & $201,45 \mathrm{p}$ & $26,83 \mathrm{p}$ & $34,55 \mathrm{p}$ & $33,28 \mathrm{p}$ & $8,69 \mathrm{p}$ \\
Factorial & $2,59 \mathrm{x}$ & $0,83 \mathrm{x}$ & $202.02 \mathrm{x}$ & $25,88 \mathrm{x}$ & $34.02 \mathrm{x}$ & $38,40 \mathrm{x}$ & $10,27 \mathrm{x}$ \\
Control & $2,33 \mathrm{x}$ & $1,20 \mathrm{x}$ & $174,61 \mathrm{x}$ & $29,44 \mathrm{x}$ & $29,44 \mathrm{x}$ & $29,10 \mathrm{x}$ & $2,33 \mathrm{x}$ \\
Interaction & $(-)$ & $(-)$ & $(-)$ & $(-)$ & $(-)$ & $(-)$ & $(-)$ \\
\hline
\end{tabular}

Note : Different notation in the same column/row indicated the significantly differences at $5 \%$ F-test

F. The Examination of RP-Etp5 Inoculum Concentration and Application Method

The examination results on the effect of inoculum concentration and application method on Kudzu plant infection and nodulation activity at week 10 are presented in Table 9 below. There was no interaction between the two treatments. Both the concentration of $2 \mathrm{ml} /$ plant or $4 \mathrm{ml} /$ plant gives a relatively equal effect on the formation of nodules. Meanwhile, direct inoculation to the crop provides a better benefit because it gives the higher actual total number of nodules, although it is relatively not significantly different from the uninoculated controls.

Table 9. Effect of inoculum concentration and application method on infection and nodulation activity of Kudzu plants at week 10

\begin{tabular}{lcccc}
\hline \multicolumn{1}{c}{ Treatment } & $\begin{array}{c}\text { Total } \\
\text { Number of } \\
\text { Nodule }\end{array}$ & $\begin{array}{c}\text { Number of } \\
\text { Effective } \\
\text { Nodule }\end{array}$ & $\begin{array}{c}\text { Persentage of } \\
\text { Effective } \\
\text { Nodule (\%) }\end{array}$ & $\begin{array}{c}\text { Total } \\
\text { Weight of } \\
\text { Nodule (g) }\end{array}$ \\
\hline Conc. $2 \mathrm{ml} / \mathrm{tan}$ & $74,33 \mathrm{a}$ & $67,67 \mathrm{a}$ & $85,37 \mathrm{a}$ & $0,37 \mathrm{a}$ \\
Conc. $4 \mathrm{ml} / \mathrm{tan}$ & $62,83 \mathrm{a}$ & $58,50 \mathrm{a}$ & $91,46 \mathrm{a}$ & $0,43 \mathrm{a}$ \\
Direct application at planting time & $94,83 \mathrm{p}$ & $87,33 \mathrm{p}$ & $90,46 \mathrm{p}$ & $0,59 \mathrm{p}$ \\
Weekly inoculationin 2 weeks & $42,33 \mathrm{q}$ & $38,83 \mathrm{p}$ & $86,36 \mathrm{p}$ & $0,22 \mathrm{p}$ \\
Factorial & $68,58 \mathrm{x}$ & $63,08 \mathrm{x}$ & $88,41 \mathrm{x}$ & $0,40 \mathrm{x}$ \\
Control & $60,67 \mathrm{x}$ & $58,00 \mathrm{x}$ & $95,67 \mathrm{x}$ & $0,64 \mathrm{x}$ \\
Interaction & $(-)$ & $(-)$ & $(-)$ & $(-)$ \\
\hline Not:
\end{tabular}

Note : Different notation in the same column/row indicated the significantly differences at $5 \%$ F-test

There is no interaction between the two treatments was also found to be the effect of treatment on the growth of plant length, the number of segments, the fresh weight, the dry weight of the plant, and the effectiveness of the symbiosis (Table 10). Giving inoculum with equal amount of 2 and $4 \mathrm{ml} /$ plant relative give the same effect to plant growth. 
In the meantime, direct inoculum application at planting time provides better benefits because it gives the number of segments, the fresh weight of the plant, the dry weight of the plant and the apparent symbiotic effectiveness is higher than the weekly incubation gradually over an interval of 1 week.

Table 10. Effect of inoculation concentration and application method on plant growth at week 10

\begin{tabular}{|c|c|c|c|c|c|}
\hline Treatment & $\begin{array}{c}\text { Plant } \\
\text { length }(\mathrm{cm})\end{array}$ & $\begin{array}{c}\text { Number of } \\
\text { segment }\end{array}$ & $\begin{array}{c}\text { Plant fresh } \\
\text { wt (g) }\end{array}$ & $\begin{array}{c}\text { Plant dry } \\
\text { wt (g) }\end{array}$ & $\begin{array}{l}\text { Effectiveness } \\
\text { of Symbiosis }\end{array}$ \\
\hline Conc. $2 \mathrm{ml} / \mathrm{tan}$ & $122,79 \mathrm{a}$ & $19,28 \mathrm{a}$ & $23,27 \mathrm{a}$ & $4,70 \mathrm{a}$ & $0,17 \mathrm{a}$ \\
\hline Conc. $4 \mathrm{ml} / \mathrm{tan}$ & $114,42 \mathrm{a}$ & $19,05 \mathrm{a}$ & $20,20 \mathrm{a}$ & $4,08 \mathrm{a}$ & $-9,35$ a \\
\hline Direct application at planting time & $140,03 \mathrm{p}$ & $20,44 \mathrm{p}$ & $26,13 \mathrm{p}$ & $5,27 \mathrm{p}$ & $14,45 \mathrm{p}$ \\
\hline Weekly inoculationin 2 weeks & $97,18 \mathrm{p}$ & $17,89 \mathrm{q}$ & $17,34 \mathrm{q}$ & $3,10 \mathrm{q}$ & $-23,64 q$ \\
\hline Factorial & $118,60 x$ & $19,17 x$ & $21,74 \mathrm{x}$ & $4,39 \mathrm{x}$ & $-5,60 x$ \\
\hline Control & $101,11 x$ & $18,22 \mathrm{x}$ & $21,13 \mathrm{x}$ & $4,60 x$ & $0,00 \mathrm{y}$ \\
\hline Interaction & $(-)$ & $(-)$ & $(-)$ & $(-)$ & $(-)$ \\
\hline
\end{tabular}

Note : Different notation in the same column/row indicated the significantly differences at $5 \%$ F-test

Table 11. Interaction between inoculum concentration and application method to the growth of leaf number, root fresh weight and root dry weight at week 10

\begin{tabular}{llcr}
\hline \multicolumn{1}{c}{ Treatment } & Leaves number & $\begin{array}{c}\text { Root fresh weight } \\
\text { (g) }\end{array}$ & Root dry weight (g) \\
\hline Conc. $2 \mathrm{ml} / \mathrm{tan}$ & & 1,82 & 0,49 \\
Conc. $4 \mathrm{ml} / \mathrm{tan}$ & 27,55 & 1,56 & 0,51 \\
Direct application at planting time & 27,00 & 1,99 & 0,57 \\
Weekly inoculationin 2 weeks & 33,17 & 1,39 & 0,42 \\
Conc 2 ml/plant, direct inoculation & 21,39 & $1,67 \mathrm{a}$ & $0,43 \mathrm{bc}$ \\
Conc 2 ml/plant, weekly inoculation & $29,00 \mathrm{a}$ & $1,97 \mathrm{a}$ & $0,56 \mathrm{ab}$ \\
Conc $4 \mathrm{ml} /$ plant, direct inoculation & $26,11 \mathrm{ab}$ & $2,31 \mathrm{a}$ & $0,72 \mathrm{a}$ \\
Conc $4 \mathrm{ml} /$ plant, weekly inoculation & $37,33 \mathrm{a}$ & $0,81 \mathrm{~b}$ & $0,31 \mathrm{c}$ \\
Factorial & $16,67 \mathrm{~b}$ & $1,69 \mathrm{x}$ & $0,50 \mathrm{x}$ \\
Control & $27,28 \mathrm{x}$ & $2,41 \mathrm{x}$ & $0,78 \mathrm{x}$ \\
Interaction & $25,80 \mathrm{x}$ & $(+)$ & $(+)$
\end{tabular}

Note: Different notation in the same column/row indicated the significantly differences at 5\% F-test

Interactions were found over the $\mathrm{ml} /$ plant given directly at planting time, or 2 number of leaves, fresh weight and dry weight $\mathrm{ml} /$ plant but repeated a week later (Table 11). of the roots. In order for the number of leaves, fresh weight and dry weight of roots to reach the maximum, then the required inoculum is 4 


\section{CONCLUSIONS}

Based on the observation, it can be concluded that:

1. From the isolation and purification of Rhizobium bacteria from wild Kudzu roots obtained 5 selected isolates, there are : RP-Etp2 (incompatible isolate); RPEtp1 and RP-Etp3 (low-compatibility isolates), RP-Etp5 (mediumcompatibility isolate) and RP-Etp4 (high compatibility isolate).

2. To multiply the number of inoculums, the isolates should be incubated on the Yeast Mannitol Broth (YMB) medium for 48 hours as the number of cells has reached the maximum.

3. From RP-Etp4 reinoculation testing (high compatibility) it is known that broth inoculum has advantages over solid inoculum (in peat) because it gives the highest number of nodules.

4. The number of equivalent inoculums 2 and $4 \mathrm{ml} / \mathrm{plant}$ gives the same effect on infection activity and bacterial nodulation of isolate RP-Etp4 and RP-Etp5, and gives the same effect to the growth of inoculated plants with RP-Etp5.

5. For reinoculation of RP-Etp5 to the Kudzu plants (medium compatibility), can be used as inoculum with concentration of $4 \mathrm{ml} /$ plant directly applied at planting time or concentration $2 \mathrm{ml} /$ plant weekly applied in 2 weeks.

\section{ACKNOWLEDGEMENT}

This research is a part of the umbrella research conducted in the Muhammadiyah University of Yogyakarta. So, I thankfully appreciate Mrs. Agung Astuti, Mr. Bambang Heri Isnawan and Mrs. Lilik Utari as the research colleagues.

\section{REFFERENCES}

Allen, A., AlFritzh, S. J., \& Spencer, M. (2000). Kudzu (Pueraria lobata). ASPI Publications. (Http://www.tp55.htm)

Ashton, M. (2017). Benefits of Kudzu Isoflavones. Acces from http://www.livestrong.com/article/411 394-benefits-of-kudzu-isoflavones/

Elkan, G. H. (1987). Symbiotic Nitrogen Fixation Technology. Departemen of Microbiology North Carolina State University Raliegh, North Carolina.

Isnawan, B. H., Astuti, A., Sudarsono, D. S., Utari, L., Triwahyuningsih, N., Rahmawati, N., \& Sriyadi. (2003). Kajian Penerapan Inovasi Teknologi untuk Pengembangan Pertanian Terpadu di Lahan Pasir Pantai. Laporan Penelitian BAPPEDA Kulonprogo - Fakultas Pertanian UMY, Yogyakarta.

Lehmann, J., da Silva Jr, J. P., \&Trujillo, L. (2000). Legume cover crop and nutrient cycling in tropical fruit. Acta Horticulturae, 531, 65-72.

Triwahyuningsih, N., Utari, L., Sumarlan, S., Pristiwantoro, E. C., \& Utomo, T. Y. (2005). Kajian Inokulasi Rhizobium sp. Indigenus Rhizosfer dan Endofitik Bintil Akar, Pengaruhnya Terhadap Aktivitas Infeksi, Nodulasi dan Pertumbuhan Tanaman Kerandang (Pueraria phaseoloides) di Tanah Regosol Pasir Pantai dan Regosol Vulkanik. Fakultas Pertanian UMY. 
Setiadi, Y. (1990). Aplikasi Mikrobia Tanah Sebagai Salah Satu Terapan Dalam Bioteknologi Kehutanan. Dalam Rangka Penataran II Dosen DTS Bidang Rekayasa Genética. Bogor. 88p.

Shores, M. (2005). The Amazing Story of Kudzu. http://www.Max_Shores.com/ Tortora, GJ. 2001. Microbiology. Benyamin Cummings, an Imprint of Addison Wesley Longman. Inc. 